\title{
Synergy of crude enzyme cocktail from cold-adapted Cladosporium cladosporioides Ch2-2 with commercial xylanase achieving high sugars yield at low cost
}

\author{
Lei Ji, Jinshui Yang, Hua Fan, Yi Yang, Baozhen Li, Xuejian Yu, Ning Zhu and Hongli Yuan*
}

\begin{abstract}
Background: The efficiency and cost of current lignocellulosic enzymes still limit the large-scale production of cellulosic ethanol in industry. Residual lignin after pretreatment severely depresses the activity of polysaccharide hydrolases and the $\mathrm{h}$ ydrolysis of holocellulose. If we include in hydrolase mixture construction the ligninase involved in lignin degradation, which mainly includes laccase, manganese peroxidases (MnP) and lignin peroxidase (LiP), it is feasible that this could greatly improve the fermentable sugars yield.

Results: The psychrophilic lignocellulosic enzymes system of Cladosporium cladosporioides Ch2-2 including ligninase and polysaccharide hydrolases was suitable for selective delignification and efficient saccharification of biomass with wide thermal adaptability. The purified laccase was optimally active at $15^{\circ} \mathrm{C}$ and $\mathrm{pH} 3.5$, exhibiting high thermostability over a broad range of temperatures (between 4 and $40^{\circ} \mathrm{C}$ ). In addition, manganese-independent peroxidase (MIP), a special type of ligninase with the capacity to oxidize dimethyl phthalate (DMP) in the absence of $\mathrm{H}_{2} \mathrm{O}_{2}$ and $\mathrm{Mn}^{2+}$, was optimally active at $20^{\circ} \mathrm{C}$ and $\mathrm{pH} 2.5$, exhibiting high thermostability over a broad range of temperatures ( 4 and $28^{\circ} \mathrm{C}$ ), while depressed completely by $\mathrm{Fe}^{2+}$ and essentially unaffected by EDTA. Synergy between Ch2-2 crude enzymes and commercial xylanase obviously enhanced biomass hydrolysis, which could take the place of expensive commercial cellulase mixture. The maximum value of synergistic degree reached 4.7 at $28^{\circ} \mathrm{C}$, resulting in $10.1 \mathrm{mg} / \mathrm{mL}$ reducing sugars.
\end{abstract}

Conclusions: The psychrophilic enzymes system of C. cladosporioides Ch2-2 with a different synergistic mechanism has huge potential for the enhancement of biomass hydrolysis at mesophilic and low temperatures. The application scope of the lignocellulosic enzyme cocktail could be greatly enlarged by optimizing the operation conditions specific to the characteristics of ligninase.

Keywords: Cladosporium cladosporioides, Cold adaptation, Laccase, MIP, Polysaccharide hydrolases, Synergy, Commercial xylanase

\footnotetext{
* Correspondence: hlyuan@cau.edu.cn

State Key Laboratory of Agrobiotechnology, MOA Key Laboratory of Soil Microbiology and National Energy R \& D Center for Non-food Biomass, College of Biological Sciences, China Agricultural University, Beijing 100193, China
} 


\section{Background}

Making full use of biomass such as agricultural waste and energy crops to produce clean fuel ethanol on an industrial scale is beneficial to solve the crisis of environmental pollution and energy shortage. Sugarcane bagasse is one of the most abundant byproducts of agroindustry in south China as well as the world [1]. Meanwhile, Jerusalem artichoke is a typical example of the energy crops which can grow in marginal lands, including saline soils and sandy soils, owing to its unique agronomic traits such as tolerance to salt and drought stresses, and thus does not compete for arable lands with grain crops [2]. As a sustainable feedstock, bagasse and Jerusalem artichoke stalks are both considered to be applicable for the large-scale biological production of cellulosic ethanol and other biobased chemicals. However, the low efficiency and high cost of existing enzymes converting lignocellulose to fermentable sugars still limit the large-scale industrialization of cellulosic ethanol at present. In this respect, the synergistic action of lignocellulosic enzymes has been recognized as a possible way to improve sugars yield at lower enzyme loadings [3].

Synergy between cellulase and xylanase has been extensively studied in prior research [3]. Hu et al. showed that cellulose and xylan hydrolysis occurred three times faster when adding an optimized mixture of commercial cellulase and xylanase instead of equivalent cellulase [4]. The synergistic interaction between endo-xylanase from family GH10 and xyloglucanase from family GH5 also enhanced the hydrolytic activity of commercial cellulase over a range of pretreated lignocellulosic substrates [5]. Additionally, Schilling et al. found that the significant increase in saccharification efficiency through xylanaseaided synergism was not limited to same-species enzyme sources [6]. However, these synergistic reactions were almost held at $50^{\circ} \mathrm{C}$ or thereabout, according to the optimum temperature of cellulase and xylanase [7], which could not fully meet the demands for application at environment temperatures.

However, synergistic cooperation between ligninase and polysaccharide hydrolases during biomass degradation has been largely ignored. Due to the complexity of the structure of the plant cell wall, lignin is hard to totally remove after pretreatment with current methods [8]. The hydrolase activities and total sugars yield are severely reduced by the residual lignin component and its related derivatives. It was showed that various cellulases and xylanases differed by up to 3.5 -fold and 1.7-fold respectively in their inhibition by lignin [9]. Grabber et al. indicated that reduction of lignin content or ferulate-lignin crosslinking would improve the fermentation of cellulose and hemicellulose more than current approaches for shifting lignin composition [10]. In a recent study, a higher reducing sugars conversion (60\%) was achieved when adding commercial laccase into a mixture of cellulases and hemicellulases at $45^{\circ} \mathrm{C}$ [11]. Therefore, ligninase should be taken into account in enzyme cocktail construction for saccharification in order to maximize the hydrolysis efficiency.

One special kind of ligninase MIP receiving little attention in recent years may play a different role in lignin degradation [12,13]. It was first reported in the extracellular fluid of the white-rot fungus Bjerkandera sp. BOS55 as having the capacity to oxidize DMP in the absence of $\mathrm{H}_{2} \mathrm{O}_{2}$ [12]. In contrast with MnP, MIP was not inhibited by $1 \mathrm{mM}$ EDTA and was not stimulated by $\mathrm{Mn}^{2+} \mathrm{Mn}^{2+}$ addition [14-16]. In view of its simpler substrate oxidation mode, the function of MIP in the complex synergistic system of lignocellulosic enzymes still needs to be clarified.

Lignocellulosic fungus Cladosporium cladosporioides was reported to secrete laccase, MnP, LiP, cellulases and hemicellulases. Several laccases have been purified from the culture supernatant of $C$. cladosporioides, which usually showed relative activities over a range of $\mathrm{pH} 3$ to 6 and 40 to $70^{\circ} \mathrm{C}[17,18]$. Previous research of C. cladosporioides mostly focused on its good capacity for dye decolorization and various enzyme activities in mesophilic temperatures $[7,19,20]$. There was only one report about psychrophilic C. cladosporioides, which was isolated from Antarctica at either $4^{\circ} \mathrm{C}$ or $15^{\circ} \mathrm{C}$ with the ability to produce endoglucanase [21]. Further studies about psychrotolerant $C$. cladosporioides secreting ligninase and polysaccharide hydrolases in biomass degradation will considerably enlarge its application range.

Cold-adapted microorganisms have a considerable potential in biotechnological application, including waste treatment and bioremediation at ambient temperatures, textile and food industries [22,23]. Bioconversion catalyzed by cold-adaptive enzymes produced by these psychrophilic microorganisms have three advantages, firstly they have the potential to economize processes by saving energy because of their high activity at low and moderate temperatures and thus offer potential economic and environmental benefits [23]. Secondly, mild industrial conditions at an ambient temperature are beneficial for preventing modification of original heat-sensitive substrates and generation of adverse by-products [24]. Thirdly, the application of psychrophilic enzymes will make the industrial operation more convenient and safer, which is a tendency in traditional industry [24].

In our previous work a lignin-degrading psychrophilic fungus strain C. cladosporioides Ch2-2 was isolated from Changbai Mountain (China) forest soil, which was able to remove basic dye effectively [25]. In this study the lignocellulose degradation characteristic of psychrophilic C. cladosporioides secreting laccase, MIP, cellulases and hemicellulases will be investigated for the first time. 
According to the cold-adapted property of purified laccase and MIP, hydrolysis was greatly enhanced at either temperate or low temperature through synergy between Ch2-2 crude enzymes and commercial xylanase. The results will provide new perspectives to create lignocellulosic enzyme cocktails with a lower cost and higher efficiency.

\section{Results}

Psychrophilic adaptability of C. cladosporioides Ch2-2

C. cladosporioides Ch2-2 was cultured in GPY medium under different temperatures for 7 days separately, and then dry weights were measured. Data showed that Ch22 was able to keep almost the same high dry weight $(1.31$ to $1.74 \mathrm{~g})$ in the temperature range from $10^{\circ} \mathrm{C}$ to $28^{\circ} \mathrm{C}$ while the optimal growth temperature was $15^{\circ} \mathrm{C}$ $(1.74 \mathrm{~g})$ (Figure $1 \mathrm{~A})$. It indicated that $\mathrm{Ch} 2-2$ was a psychrophilic fungus with wild thermal adaptability, whether in normal or in low temperature.

Along with the growth of Ch2-2, laccase activity was checked, which was reported to be connected with

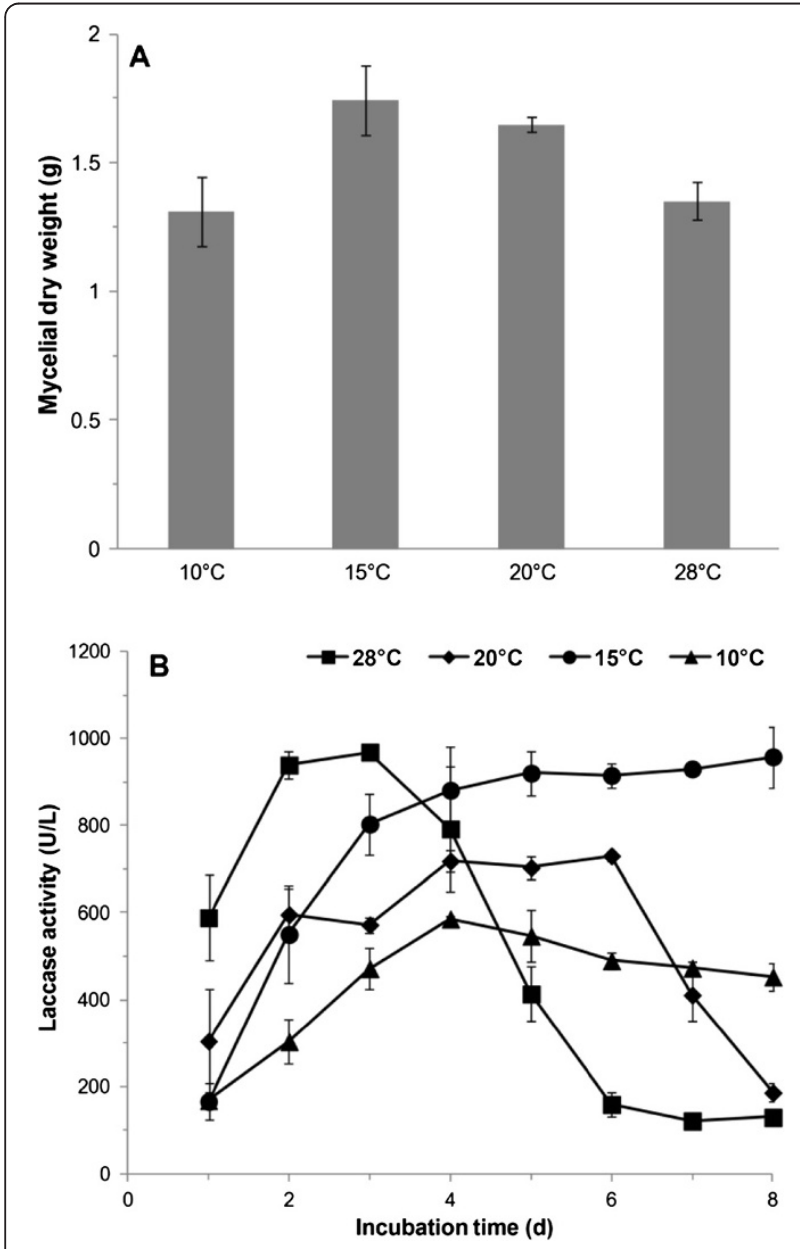

Figure 1 Effects of different temperatures on growth $(A)$ and laccase production (B) of C. cladosporioides Ch2-2 after 7 days incubation. decolorization of basic dye [25]. As shown, from the first day of incubation laccase was secreted, whether in low temperature $\left(10^{\circ} \mathrm{C}\right)$ or in normal temperature $\left(28^{\circ} \mathrm{C}\right)$ (Figure 1B). In accordance with the optimal growth temperature, $15^{\circ} \mathrm{C}$ was found to be best for the stability of laccase production. It could reach almost the maximum $(920 \mathrm{U} / \mathrm{L})$ on the fourth day, and then maintain this level for at least another 4 days. In addition, it reached this activity peak $(968 \mathrm{U} / \mathrm{L})$ quicker at $28^{\circ} \mathrm{C}$ on the third day, however it could not maintain this level for as long. Even at $10^{\circ} \mathrm{C}$, laccase activity was able to reach $600 \mathrm{U} / \mathrm{L}$ on the fourth day. The temperature property of laccase from Ch2-2 corresponding to the host fungus will assign it a more widespread application value.

\section{Synergistic action of inducible enzymes from $C$.} cladosporioides Ch2-2 during the degradation of bagasse In order to investigate the biomass degradation capability of C. cladosporioides Ch2-2, the main composition of its lignocellulosic enzymes system and the relationship between biodegradation and secretion regularity of enzymes, we tracked the changes of lignocellulosic enzyme activities and relevant component degradation rates during the bio-pretreatment and saccharification process of bagasse. It was found that, in addition to laccase, a variety of other inducible lignocellulosic enzymes could be produced by Ch2-2 including cellulase, xylanase and MIP, which was able to deconstruct lignin through oxidation without $\mathrm{Mn}^{2+}$. In the present study LiP activity was not detected. The secretion pattern of these enzymes was closely linked to the composition and structure of lignocellulose, which could cause obvious degradation rate changes of corresponding components.

It was found that the activities of ligninase (laccase and MIP) were growing at a rapid rate from the beginning, following the fast degradation of lignin (Figure 2A, B). On day 14, MIP reached the maximum (51.0 U/L) and laccase also achieved its high activity level (83.2 U/L), which was sustained until day 25, further accelerating the degradation rate of lignin. During the first 25 days, the lignin degradation percentage was the highest $(41.8 \%)$ as compared with that of other components, while the degradation percentages of cellulose and hemicellulose were $16 \%$ and $24.7 \%$, respectively. After that, the activities of laccase and MIP showed a declining trend leading to a slow degradation rate of all the three components simultaneously until day 55 when the lignin content had almost reached the stable value. In contrast, cellulose began to be markedly reduced along with the slow decline of hemicellulose when the filter paper activity (FPA) was close to the peak (Figure 2A, B). When FPA was at its minimum, the cellulose content became almost stable. In accordance with the degradation regularity of cellulose, the peak of xylanase 

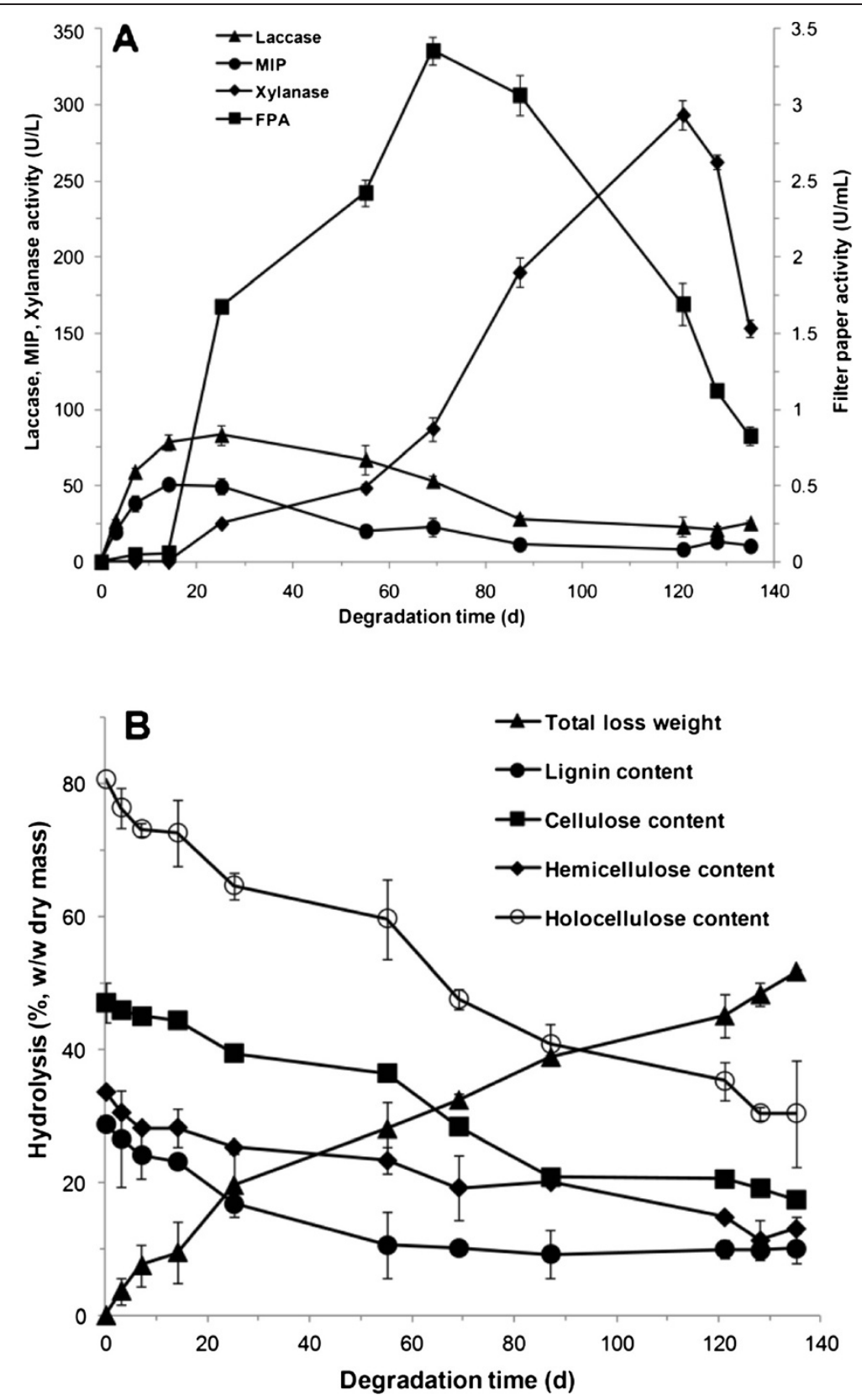

Figure 2 Inducible lignocellulosic enzymes (laccase, MIP, cellulase and xylanase) (A) and changes of lignocellulose component contents (B) during bagasse degradation by C. cladosporioides $\mathrm{Ch} 2-2$ at $28^{\circ} \mathrm{C}$.

activity on day 120 (293.5 U/L) corresponded with the increased degradation rate of hemicellulose. After 135 days the total weight loss of bagasse was $51.6 \%$, in which the losses of lignin, cellulose and hemicellulose were $65.5 \%$, $62.8 \%$ and $61.5 \%$, respectively.

These results indicated that multiple lignocellulosic enzymes of Ch2-2 were an efficient natural synergy system with a clear selective secretion pattern, which was induced by the specific components of bagasse. Even more importantly, it was found that the degradation rate of lignin limited that of the holocellulose to some extent.

\section{Ligninase purification and properties}

The important role of C. cladosporioides Ch2-2 ligninase during the degradation process was mentioned above, which was crucial in order for cellulases and hemicellulases to carry out their roles sufficiently. In order to 
further analyze the ligninase characteristic, laccase and MIP were purified and studied.

The molecular weight of laccase was about $70 \mathrm{kDa}$ as measured by SDS-PAGE (Figure 3A). Its optimal temperature and $\mathrm{pH}$ were $15^{\circ} \mathrm{C}$ and $\mathrm{pH} 3.5$, respectively (Figure 4A, D). It was stable at a very wide temperature and $\mathrm{pH}$ range of 4 to $40^{\circ} \mathrm{C}$ and $\mathrm{pH} 2.0$ to 5.5 (Figure 4B, D). Using ABTS as a substrate, the $K_{\mathrm{m}}$ and $V_{\max }$ for laccase were $2.8 \mu \mathrm{M}$ and $57.9 \mu \mathrm{mol} / \mathrm{min} / \mathrm{mg}$ under the optimal conditions. Laccase activity was inhibited by $2 \mathrm{mM}$ of $\mathrm{Fe}^{2+}(5.36 \%)$, SDS (27.2\%) and was slightly inhibited by EDTA (74.6\%) at a concentration of $10 \mathrm{mM}$, and essentially unaffected by $2 \mathrm{mM}$ of EDTA (98.0\%), $10 \mathrm{mM}$ of $\mathrm{Cu}^{2+}(105 \%)$ and $\mathrm{Al}^{3+}(104 \%)$.

The molecular weight of purified MIP from Ch2-2 was about $47 \mathrm{kDa}$ (Figure 3B). Its optimal temperature and $\mathrm{pH}$ were $20^{\circ} \mathrm{C}$ and $\mathrm{pH} 2.5$ respectively (Figure 4A, D), indicating the low temperature adaptation. It was also stable at a wide temperature and $\mathrm{pH}$ range of 4 to $28^{\circ} \mathrm{C}$ and $\mathrm{pH} 2.0$ to 5.5 (Figure 4C, D). Using DMP as a substrate without $\mathrm{H}_{2} \mathrm{O}_{2}$, the $K_{\mathrm{m}}$ and $V_{\max }$ of MIP were $6.9 \mu \mathrm{M}$ and $38.3 \mu \mathrm{mol} / \mathrm{min} / \mathrm{mg}$ under optimal conditions. The MIP activity was $100 \%$ depressed by $2 \mathrm{mM}$ of $\mathrm{Fe}^{2+}$ and essentially unaffected by EDTA (97.7\%) at a concentration of 10 $\mathrm{mM}$.

From enzymatic characteristics of purified enzymes, we found that both laccase and MIP from Ch2-2 exhibited substantially wide thermal adaptability in a mesophilic and psychrophilic environment, and MIP exhibited a special property that correlated with functional mechanism.

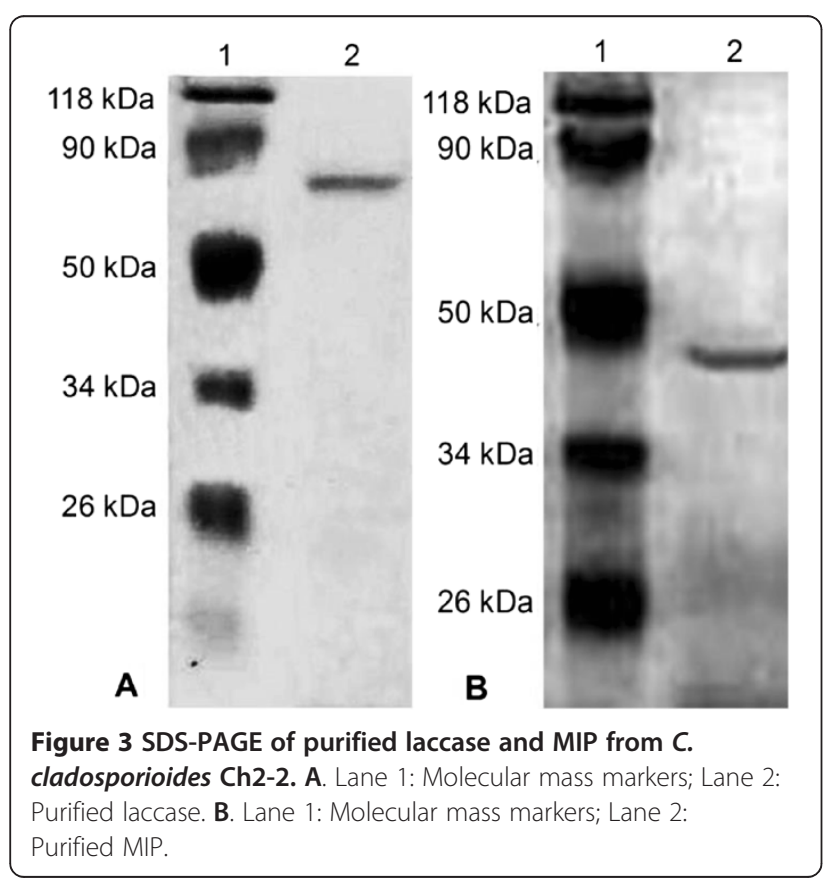

\section{Hydrolysis of biomass by enzymes preparation from C. cladosporioides $\mathrm{Ch} 2-2$}

According to the properties of purified laccase and MIP, synergy between Ch2-2 crude enzymes and commercial cellulase or xylanase in converting milled Jerusalem artichoke stalks into reducing sugars was assessed under different temperatures. If it was treated at $15^{\circ} \mathrm{C}$ for one day according to the optimum temperature of ligninase, and then at $50^{\circ} \mathrm{C}$ for four days in order to be fit for the commercial cellulase and xylanase, synergy was exhibited in all four types of mixture (Figure 5A). The degree of synergism (DS) between Ch2-2 enzymes and commercial xylanase reached the maximum value of 3.4 on day 2, which was followed by the substantial increase of reducing sugars $(7.8 \mathrm{mg} / \mathrm{mL})$. However, the highest reducing sugars yield was obtained by the mixture containing Ch2-2 enzymes, commercial cellulase and xylanase together on day $5(10.9 \mathrm{mg} / \mathrm{mL})$, which was much higher than using any enzyme alone. Therefore, it was not due to the additive effect.

We also investigated the interaction at ambient temperatures of $28^{\circ} \mathrm{C}$ and $15^{\circ} \mathrm{C}$, respectively (Figure $5 \mathrm{~B}, \mathrm{C}$ ). It was seen that the DS between Ch2-2 enzymes and commercial xylanase almost reached the maximum value of 4.7 at $28^{\circ} \mathrm{C}$ on day 4 and then reached a high reducing sugars yield of $10.1 \mathrm{mg} / \mathrm{mL}$ later on, which was even higher than that obtained at $50^{\circ} \mathrm{C}(8.9 \mathrm{mg} / \mathrm{mL})$. During the whole hydrolysis process at $28^{\circ} \mathrm{C}$, the sugars yield obtained by the mixture of Ch2-2 enzymes and commercial xylanase kept almost at the same level as that obtained by the three enzymes combined. Furthermore, the interaction also showed cold-adapted synergistic effect at $15^{\circ} \mathrm{C}$ with a maximum DS of 4.1 on day 5 . The reducing sugars production could be improved 295\% through synergistic effect between Ch2-2 enzymes and commercial xylanase on day $5(7.9 \mathrm{mg} / \mathrm{mL})$, which was not greatly affected by the low temperature.

The reducing sugar production from milled Jerusalem artichoke stalks and the synergy effect between enzymes were further assessed under $28^{\circ} \mathrm{C}$ and $15^{\circ} \mathrm{C}$ when the loading of commercial cellulase and xylanase were reduced proportionally to one fifth; $0.05 \mathrm{~g}$ cellulase/g substrate ( $25 \mathrm{mg}$ protein/g cellulose) and $0.3 \mathrm{~g}$ xylanase/g substrate (26 mg protein/g cellulose), respectively (Figure 6A, B). The results showed that the best synergistic effect still occurred between Ch2-2 enzymes and commercial xylanase, with a DS of 2.6 and a reducing sugar level of $4.6 \mathrm{mg} / \mathrm{mL}$ on day $4\left(28^{\circ} \mathrm{C}\right)$, while the concentration of reducing sugar reached $4.1 \mathrm{mg} / \mathrm{mL}$ through the ternary mixtures. Coldadapted synergistic effect at $15^{\circ} \mathrm{C}$ between Ch2-2 enzymes and commercial xylanase remained maximum with a DS of 2.4 and a reducing sugar level of $3.3 \mathrm{mg} / \mathrm{mL}$.

The results indicate that crude enzymes mixture containing ligninase from C. cladosporioides Ch2-2 was able 

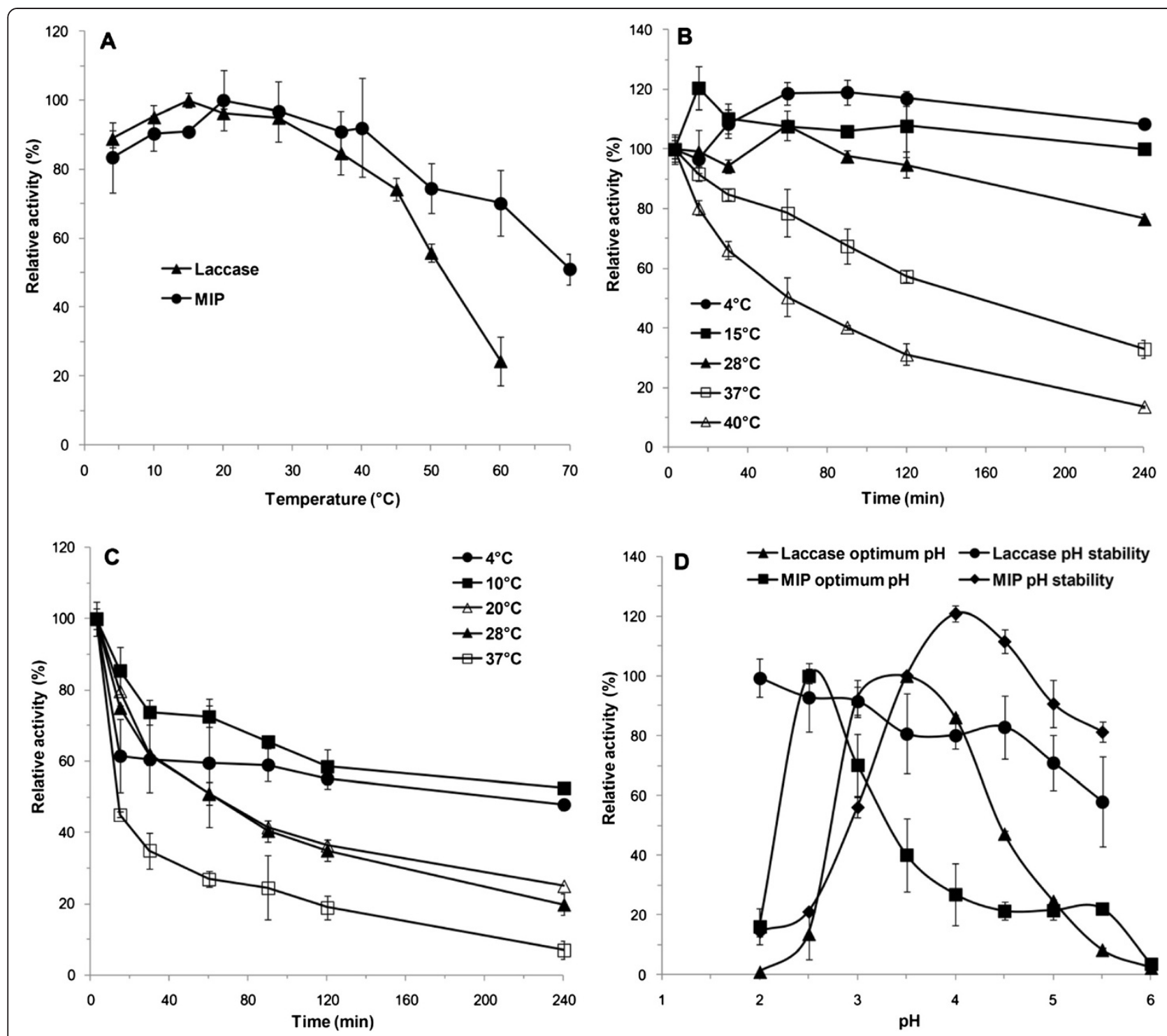

Figure 4 Effects of pH and temperature on the activity and stability of purified laccase and MIP from C. cladosporioides Ch2-2. A. Effects of temperatures on laccase and MIP activity. B. The thermostability of laccase. C. The thermostability of MIP. D. Optimal pH and pH stability of laccase and MIP. The residual activity was monitored, and the maximum activity was defined as 100\% (A, D) or initial activity was defined as $100 \%(B, C)$. Values shown were the mean of the average of three experiments.

to enhance hydrolysis of other polysaccharide hydrolases significantly over a wide temperature range, which has a promising prospect for application in biomass degradation and high-value energy production at ambient temperature. It could provide a novel guidance for the design and operation of lignocellulosic enzyme cocktails with efficient synergistic effect.

\section{Discussion}

In the overall process of lignocellulosic ethanol production, the cost of enzymes accounts for around 50 to $60 \%$ [26], with energy consumption being close behind [27].
Energy is mainly consumed in biomass pretreatment, saccharification and fermentation and so on. The expensive cost of enzymes and energy limits the market of cellulosic ethanol, and so a dramatic reduction in enzyme and energy use is extremely necessary to enhance competitiveness. In this study, psychrophilic C. cladosporioides Ch2-2 was found to be effective in bio-pretreatment and saccharification on bagasse. At the same time, synergy of crude enzymes from Ch2-2 with commercial xylanase greatly enhanced saccharification of milled Jerusalem artichoke stalks at $28^{\circ} \mathrm{C}$. In view of the application temperature, when using the most common industrial 
Figure 5 Improved production of reducing sugars from milled Jerusalem artichoke stalks by synergy of Ch2-2 enzymes and commercial cellulase or xylanase. A. Hydrolysis by binary (commercial cellulases/xylanase, commercial cellulases/Ch2-2 enzymes and commercial xylanase/Ch2-2 enzymes) or ternary mixtures (commercial cellulases/xylanase/Ch2-2 enzymes) at $15^{\circ} \mathrm{C}$ for 24 hours and then $50^{\circ} \mathrm{C}$ for 96 hours. B. Hydrolysis by binary or ternary mixtures at $28^{\circ} \mathrm{C}$ for 120 hours. C. Hydrolysis by binary or ternary mixtures at $15^{\circ} \mathrm{C}$ for 120 hours. Substrate control: milled Jerusalem artichoke stalks without enzymes. Enzyme control: reactions with each enzyme (commercial cellulases, commercial xylanase or Ch2-2 enzymes) alone.

strain Saccharomyces cerevisiae for ethanol fermentation, saccharification and fermentation could be unified at its optimum growth temperature.

During the degradation of bagasse, both the secretion of lignocellulosic enzymes and the decrease of corresponding lignocellulose components were much more selective by fungus $C$. cladosporioides $\mathrm{Ch} 2-2$ than by the three white-rot fungi reported by Dong et al. [28]. For the same lignocellulosic substrate, different fungi possessed unique degradation strategies by producing distinct enzymes, which implied various synergistic manners and mechanisms in nature. The clear separate degradation pattern during different periods made Ch2-2 more suitable for selective delignification than white-rot fungi. At the same time, the pivotal role of ligninase was highlighted in this process. Laccase and MIP were released simultaneously first following lignin degradation at a higher rate compared to holocellulose. The degradation degree of lignin drastically affected the hydrolysis of holocellulose. On one hand, the residual lignin depressed the activity of polysaccharide hydrolases and the degradation rate of holocellulose $[9,10]$. On the other hand, lignin degradation could decrease non-productive adsorption of polysaccharide hydrolases and accelerate hydrolysis [29].

Ligninase from Ch2-2 showed the adaptability to moderate and low temperatures, corresponding to the growth characteristics of the host fungus. The purified laccase and MIP were stable in a wide temperature range of 4 to $40^{\circ} \mathrm{C}$ and 4 to $28^{\circ} \mathrm{C}$ respectively, which verified that Ch2-2 was a cold-adapted lignin-degrading fungus. It greatly expanded the application scope of Ch2-2 and its enzymes, including straw returning during intermittent period of farming besides cellulosic ethanol production at room temperature. In a previous report, psychrophilic enzymes produced by cold-adapted microorganisms most often displayed high thermosensitivity [30]. Higher temperatures $\left(>20^{\circ} \mathrm{C}\right)$ typically led to low densities of cells and poor extracellular enzyme production, although shortening the generation time. However, for Ch2-2, the dry cell weight and laccase activity always exhibited high levels whether at $15^{\circ} \mathrm{C}$ or at $28^{\circ} \mathrm{C}$. The thermal stable range for laccase and MIP from Ch2-2 performed the best out of the 

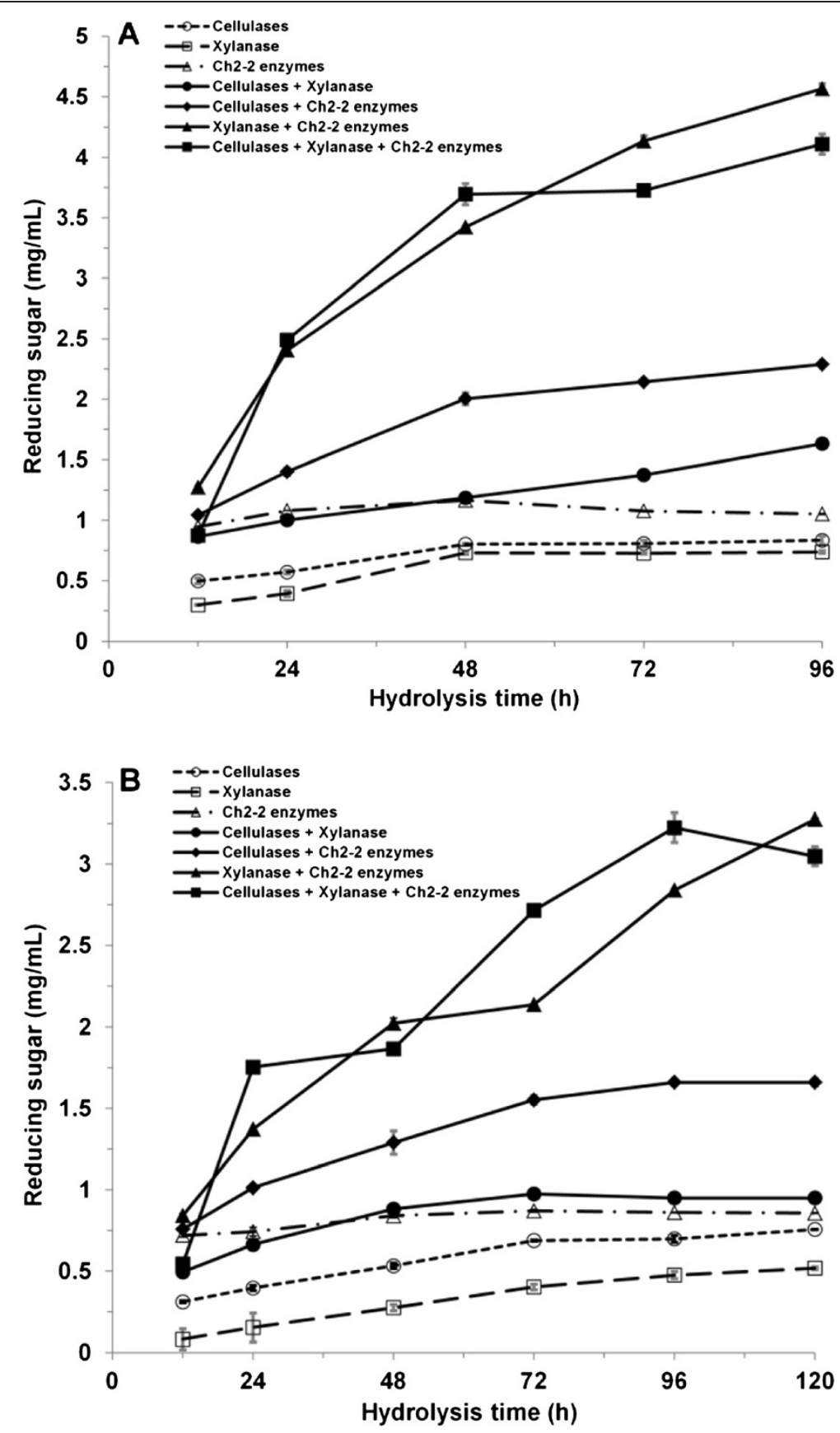

Figure 6 The changes of reducing sugar production from milled Jerusalem artichoke stalks by synergy of Ch2-2 enzymes and reduced commercial cellulase or xylanase. A. Hydrolysis by binary (commercial cellulases/xylanase, commercial cellulases/Ch2-2 enzymes and commercial xylanase/Ch2-2 enzymes) or ternary mixtures (commercial cellulases/xylanase/Ch2-2 enzymes) at $28^{\circ} \mathrm{C}$ for 96 hours. B. Hydrolysis by binary or ternary mixtures at $15^{\circ} \mathrm{C}$ for 120 hours. Substrate control: milled Jerusalem artichoke stalks without enzymes. Enzyme control: reactions with each enzyme (commercial cellulases, commercial xylanase or Ch2-2 enzymes) alone.

psychrophilic enzymes reported. Recently, many researchers have obtained thermostable polysaccharide hydrolases with good hydrolysis ability from thermophilic strains [31]. The cellulase mixture from thermophilic fungi was often evaluated at temperature 35 to $65^{\circ} \mathrm{C}$
[32], however, it was uneconomical in operation because of higher demands on devices and power consumption. Psychrotolerant enzymes have considerable application prospects in biological refining industry. At present, there are only three psychrophilic C. cladosporioides reported, 
which were obtained from wood samples in Antarctica producing more endoglucanase activity at $4^{\circ} \mathrm{C}$ than at $15^{\circ} \mathrm{C}$ after 10 days cultivation. There were no further reports about their degradation and wider mesophilic adaptabilities.

Like the digestion of novel mechanism of thermophilic Caldicellulosiruptor bescii CelA [33], psychrophilic enzymes from Ch2-2 provided the possibility of exploring a new synergy mechanism. At present, it is not clear what role MIP plays in lignin degradation. The molecular weight of laccase was higher than that reported for $\mathrm{MnP}$, which made it hard to access occluded lignin in biomass. Various low molecular weight electron transfer agents such as 1-hydroxybenzotriazole (HOBT) were usually needed by laccase to catalyze ligninolysis [34]. While MnP produced small diffusible strong oxidants that could penetrate the substrate, it needed $\mathrm{Mn}^{2+}$ induction and $\mathrm{H}_{2} \mathrm{O}_{2}$ to work $[35,36]$. However, psychrophilic MIP from Ch2-2 plays its role without $\mathrm{Mn}^{2+}$ and $\mathrm{H}_{2} \mathrm{O}_{2}$ while being essentially unaffected by EDTA and completely depressed by $\mathrm{Fe}^{2+}$, which has not been previously reported. Therefore, future studies should be directed at elucidating the mechanism that MIP serves in the ligninolytic and synergistic hydrolysis system.

Onozuka R-10 was one kind of expensive commercial cellulase mixture used in cellulose hydrolysis as reported [35], which was made of a variety of hydrolytic enzymes including endo-1, 3- $\beta$-D-glucanase, $\beta$-glucosidase, xylanase, pectinase, protease and $\alpha$-amylase. The cost of commercial xylanase from Aspergillus clavatus used in this study accounted for about one-fifteenth that of the Onozuka R-10. Their optimum range of temperature and $\mathrm{pH}$ were $40-50^{\circ} \mathrm{C}$ and $\mathrm{pH} 4.0-5.0$. During the hydrolysis of Jerusalem artichoke stalks with different enzymes combination, interaction between Ch2-2 crude enzymes and commercial xylanase exhibited maximum synergistic effect at 15,28 and $50^{\circ} \mathrm{C}$, which could take the place of an expensive commercial cellulase mixture in application. The reducing sugars yield received through the mixture of Ch2-2 enzymes and commercial xylanase here at $28^{\circ} \mathrm{C}$ ( $482.9 \mathrm{mg} / \mathrm{g}$ substrate) was much higher than that using a fungal-bacterial cocktail of pure strains at $30^{\circ} \mathrm{C}$ (165.2 mg/g substrate) within 24 hours [37]. Acquiring a considerable sugars yield from biomass at normal temperature is also profitable in providing a carbon source for microalgae lipid production by heterotrophic growth of microalgae, which often achieves maximum performance at meso-low temperatures [38]. These results provide novel information for constructing an efficient and easyoperating composite lignocellulosic enzymes mixture. In this way, the saccharification for fermentable sugars can be maximized and the bioethanol yield can be increased even at normal and low temperatures to meet the demand of bio-refinery.

\section{Conclusions}

Cold-adapted fungus C. cladosporioides Ch2-2 possesses a natural synergistic lignocellulosic enzymes system suitable for the selective delignification and efficient saccharification of biomass. Purified laccase and MIP from Ch2-2 had a wide thermal adaptability in mesophilic and low temperatures corresponding to the host fungus. MIP provided a new enzyme property in cooperation with other enzymes during biodegradation. Hydrolysis of lignocellulosic substrate was severely enhanced by synergy between crude Ch2-2 enzymes and cheap commercial xylanase, which could provide a substitute for current expensive commercial cellulase mixtures and reach a higher reducing sugars yield. The new cocktail of Ch2-2 enzymes and commercial xylanase enabled consistency of hydrolysis and fermentation at ambient temperatures. This study will provide a novel perspective of lignocellulosic enzyme construction and psychrophilic enzymes application in biotechnology, including waste treatment, high-value renewable biofuel production and bioremediation at ambient temperatures.

\section{Materials and Methods}

\section{Fungus thermal adaptability}

Seed liquid of C. cladosporioides Ch2-2 was inoculated to GPY medium ( $2 \%$ glucose, $0.5 \%$ peptone, $0.2 \%$ yeast extract, $\left.0.2 \% \mathrm{KH}_{2} \mathrm{PO}_{4}, 0.05 \% \mathrm{MgSO}_{4} / 7 \mathrm{H}_{2} \mathrm{O}, \mathrm{pH} 5.5\right)$ cultured for 7 days at 10 to $28^{\circ} \mathrm{C}$. The dry weight of mycelia was determined separately.

At the same time, the fungus solution activated in different temperatures was transferred into the optimized medium (20\% potato juice, $2 \%$ sucrose, $5 \%$ wheat-bran) for laccase production and activity detection.

\section{Enzymatic degradation}

$5 \mathrm{~g}$ of dry bagasse was added in $150 \mathrm{~mL}$ conical flasks and moistened with $30 \mathrm{~mL}$ liquid Czapek culture medium [28]. After autoclaving for 1 hour at $121^{\circ} \mathrm{C}$, each flask was inoculated with $5 \mathrm{~mL}$ seed liquid of C. cladosporioides Ch2-2 and incubated at $28^{\circ} \mathrm{C}$ [39]. In all cases, bagasse samples were treated identically but the sample without fungal inoculation served as a control. The samples were regularly tested to determine dry weight, chemical composition and enzyme activities using methods previously described [40]. All experiments were performed in triplicate.

\section{Enzymes purification}

Two major ligninase components, laccase and MIP, were isolated and purified from the fermentation broth of $C$. cladosporioides Ch2-2 using the techniques of $\left(\mathrm{NH}_{4}\right)$ ${ }_{2} \mathrm{SO}_{4}$ precipitation, anion and cation exchange chromatography. The purity of the enzymes was confirmed by SDS-PAGE [41]. 
The supernatant of three-day-old culture was collected by suction filtration and centrifugation at 7,155 $\mathrm{g}$ for 10 minutes at $4^{\circ} \mathrm{C}$. Solid ammonium sulfate was added to this supernatant up to $85 \%$ saturation and the resulting precipitate was collected by centrifugation at $11,180 \mathrm{~g}$ for 15 minutes. The precipitate was re-dissolved in $2 \mathrm{~mL}$ of $10 \mathrm{mM}$ sodium acetate buffer, $\mathrm{pH} 4.5$, and dialyzed overnight. Precipitated material was removed by centrifugation at $800 \mathrm{~g}$ for 10 minutes and the supernatant was applied to a column $(2.5 \times 20 \mathrm{~cm})$ of DEAE-Sephadex A 50. The enzyme was eluted gradually with $10 \mathrm{mM} \mathrm{pH}$ 8.0 Tris buffer with $\mathrm{NaCl}$ of $300 \mathrm{mM}, 500 \mathrm{mM}$ and $1 \mathrm{M}$ at a flow rate of $1.2 \mathrm{~mL} / \mathrm{min}$. The fraction containing maximum laccase or MIP activity was collected and desalted by dialysis.

The collection with laccase activity was applied to a column $(1 \times 40 \mathrm{~cm})$ of Sephadex G-75. The enzyme was eluted with $10 \mathrm{mM}$ pH 7.0 phosphate buffer with $\mathrm{NaCl}$ of $0.15 \mathrm{M}$ at a flow rate of $0.32 \mathrm{~mL} / \mathrm{min}$. The fraction containing maximum laccase activity was collected for further analysis [18].

The first purification step of collection with MIP activity was the same as laccase. Then it was applied to a column $(1 \times 17 \mathrm{~cm})$ of CM-Sephadex C 50. The enzyme was eluted gradually with $10 \mathrm{mM}$ pH 5.7 acetate buffer with $50 \mathrm{mM} \mathrm{NaCl}$ at a flow rate of $0.2 \mathrm{~mL} / \mathrm{min}$. The third step was as the first one with the Sephadex G-75 column $(1.5 \times 60 \mathrm{~cm})$. The fraction containing maximum MIP activity was collected for further analysis.

\section{Enzymes properties}

The optimum $\mathrm{pH}$ for laccase and MIP were determined by incubation at various $\mathrm{pH}$ conditions $(\mathrm{pH} 2.0$ to 6.0$)$ at $28^{\circ} \mathrm{C}$ for 10 minutes in $50 \mathrm{mM}$ sodium acetate buffer and malonic acid-sodium malonate buffer, respectively. The optimum temperature for the enzyme activity was determined by standard assay ranging from 4 to $70^{\circ} \mathrm{C}$ in the same buffer as above at $\mathrm{pH} 4.5$. The results were expressed as relative activity to the value obtained at either optimum temperature assay or optimum $\mathrm{pH}$ assay.

The $\mathrm{pH}$ stability of the enzymes were determined by measuring the remaining activity after incubating the enzymes at $28^{\circ} \mathrm{C}$ for 2 hours in $50 \mathrm{mM}$ sodium acetate buffer and malonic acid-sodium malonate buffer respectively from $\mathrm{pH} 2.0$ to 5.5. To determine the effect of temperature on the stability of the enzymes in the same buffer as above $(\mathrm{pH} 4.5)$, the remaining activity after incubating the enzymes for 4 hours at 4 to $40^{\circ} \mathrm{C}$ was measured. The activity of the enzyme obtained at either optimum temperature or optimum $\mathrm{pH}$ was defined as $100 \%$.

Kinetic constants of laccase and MIP were determined by measuring the initial rates at various ABTS and DMP concentrations respectively under standard reaction conditions. The $K_{m}$ and $V_{\max }$ were determined at $28^{\circ} \mathrm{C}$ by recording the effect of various concentrations (10 to 40 $\mathrm{mmol} / \mathrm{L}$ ) of ABTS and DMP separately [42].

The effects of metal ions and chemical reagents on enzyme activity of purified laccase and MIP were determined. The enzyme was incubated with each reagent for 2 hours at $28^{\circ} \mathrm{C}$ before the addition of the substrate to initiate the enzyme reaction. The activity of the enzyme without adding chemical reagents or metal ions was defined as $100 \%$.

\section{Enzymatic hydrolysis}

The freeze-drying powder of crude enzymes from C. cladosporioides Ch2-2 was used in different combinations at a loading of $0.1 \mathrm{~g} / \mathrm{g}$ substrate. The commercial cellulase (Onozuka R-10, Merck) and xylanase (BioRoYee) were assessed at a loading of $0.25 \mathrm{~g} / \mathrm{g}$ substrate and $1.5 \mathrm{~g} / \mathrm{g}$ substrate, respectively. The loading of $0.05 \mathrm{~g}$ cellulase/g substrate (25 mg protein/g cellulose) and $0.3 \mathrm{~g}$ xylanase $/ \mathrm{g}$ substrate (26 mg protein/g cellulose) were also assessed. The hydrolysis assays were carried out at $1 \%(\mathrm{w} / \mathrm{v})$ solid loading of grinding Jerusalem artichoke stalk in sodium acetate buffer $(50 \mathrm{mM}, \mathrm{pH} 4.5)$ in a $2 \mathrm{~mL}$ total volume. The reaction mixtures were mechanically shaken in an orbital shaker incubator at $15^{\circ} \mathrm{C}$ for 24 hours and then at $50^{\circ} \mathrm{C}$ for another 96 hours. The same reactions were individually performed at $15^{\circ} \mathrm{C}$ and $28^{\circ} \mathrm{C}$ up to 120 hours. The hydrolysis was terminated by boiling the reaction mixture at $100^{\circ} \mathrm{C}$ for 10 minutes to inactivate the enzymes. The supernatants collected after centrifugation at 9,300 $\mathrm{g}$ for 10 minutes for the measurement of reducing sugars. Blanks were run at the same time by incubating the substrates without enzymes. Reactions with each enzyme only were used as bases. All hydrolysis experiments were performed in triplicate and mean values and standard deviations are presented. The degree of synergism was calculated by the method described earlier [4].

\section{Analytical methods}

The fungal biomass was detected by using the ovendrying method [25]. The samples cultured at different temperatures were first vacuum-suction filtrated. Collected mycelia were washed by distilled water and dried for 24 hours at $50^{\circ} \mathrm{C}$ in an oven until the weight was constant.

FPA was measured spectrophotometrically based upon the color reaction between the degradation products (glucose) and DNS (3,5-dinitrosalicylic acid) [43]. The enzyme sample was mixed with $50 \mathrm{mM}$ citrate-phosphate buffer $(\mathrm{pH} 4.5)$ and Whatman filter paper. After incubation at $30^{\circ} \mathrm{C}$ for 60 minutes, the mixture was boiled with DNS for 5 minutes and the absorbance was measured at $520 \mathrm{~nm}$. One activity unit was defined as the amount of cellulase needed to release $1 \mu \mathrm{mol}$ of glucose equivalent sugar per minute. 
Xylanase activity was also assayed based upon the color reaction between the degradation products (xylose) and DNS. The enzyme sample was mixed with $50 \mathrm{mM}$ citratephosphate buffer ( $\mathrm{pH} 4.5)$ and 1\% Birchwood xylan. After incubation at $30^{\circ} \mathrm{C}$ for 15 minutes, the mixture was boiled with DNS for 5 minutes and the absorbance was measured at $520 \mathrm{~nm}$ [43]. One activity unit was defined as the amount of xylanase needed to release $1 \mu \mathrm{mol}$ of $x y-$ lose equivalent sugar per minute.

Laccase activity was determined using ABTS $(0.5 \mathrm{mM})$ as the reducing substrate [44]. The enzyme sample was mixed with $50 \mathrm{mM}$ sodium acetate buffer $(\mathrm{pH} 4.5)$ and ABTS. After incubation at $30^{\circ} \mathrm{C}$ for 10 minutes, the mixture was transferred into an ice-water bath to stop the reaction, and the absorbance was measured at $420 \mathrm{~nm}$. One activity unit was defined as the amount of laccase required to oxidize $1 \mu \mathrm{mol}$ of substrate per minute.

MIP activity was detected by monitoring the oxidation of DMP in the absence of $\mathrm{Mn}^{2+}$ and $\mathrm{H}_{2} \mathrm{O}_{2}$ [12]. The reaction mixture contained enzyme sample and $2 \mathrm{mM}$ DMP in $50 \mathrm{mM}$ malonic acid-sodium malonate buffer $(\mathrm{pH} 4.5)$. After incubation at $30^{\circ} \mathrm{C}$ for 10 minutes, the absorbance was measured at $468 \mathrm{~nm}$. One activity unit was defined as the amount of enzyme that produced $1 \mu \mathrm{mol}$ product per minute.

LiP activity was assessed by determining the oxidation of Azure Blue using $\mathrm{H}_{2} \mathrm{O}_{2}$ [45]. The assay system contained enzyme sample, $32 \mu \mathrm{M}$ Azure Blue and $100 \mu \mathrm{M}$ $\mathrm{H}_{2} \mathrm{O}_{2}$ in $50 \mathrm{mM}$ sodium tartrate buffer ( $\left.\mathrm{pH} 4.5\right)$. After incubation at $30^{\circ} \mathrm{C}$ for 10 minutes, the absorbance was measured at $651 \mathrm{~nm}$. One activity unit was defined as the amount of enzyme that produced $1 \mu \mathrm{mol}$ product per minute.

The quantitative analysis of chemical compositions of bagasse including lignin, cellulose and hemicellulose were performed by methods described earlier [46,47]. The reducing sugars were quantified by the DNS method [48]. The estimation of protein content was determined according to the method described in Lowry et al. [49]. All experiments were performed in triplicate and mean values and standard deviations are presented.

\section{Abbreviations \\ ABTS: 2, 2'-Azino-bis-(3-ethylbenzothiazoline-6-sulfonic acid) diammonium salt; DMP: Dimethyl phthalate; DNS: 3,5-dinitrosalicylic acid; DS: Degree of synergism; FPA: Filter paper activity; HOBT: 1-hydroxybenzotriazole; LiP: Lignin peroxidase; MIP: Manganese-independent peroxidase; MnP: Manganese peroxidases; SDS: Sodium dodecyl sulfate; SDS-PAGE: SDS-polyacrylamide gel electrophoresis.}

\section{Competing interests}

The authors declare that they have no competing interests.

\section{Authors' contributions}

$\sqcup, \mathrm{JY}$ and $\mathrm{HF}$ contributed jointly to the laboratory work reported in the manuscript. $\sqcup$ contributed to interpretation of results and writing of the manuscript. YY and $B L$ helped to prepare the freeze-drying powder of crude enzymes. XY and NZ helped to revise the manuscript. HY directed the over-all study and revised the manuscript. All authors have read and approved the final manuscript.

\section{Acknowledgements}

The National High Technology Research and Development Program of China (863 Program, number: 2011AA10A206) is gratefully acknowledged for the support of this work.

Received: 28 April 2014 Accepted: 22 August 2014

Published online: 10 September 2014

\section{References}

1. Petersen AM, Aneke MC, Görgens JF: Techno-economic comparison of ethanol and electricity coproduction schemes from sugarcane residues at existing sugar mills in Southern Africa. Biotechnol Biofuels 2014, 7:105.

2. Yuan WJ, Chang BL, Ren JG, Liu JP, Bai FW, Li YY: Consolidated bioprocessing strategy for ethanol production from Jerusalem artichoke tubers by Kluyveromyces marxianus under high gravity conditions. J App/ Microbiol 2012, 112:38-44.

3. Dyk VJS, Pletschke BI: A review of lignocellulose bioconversion using enzymatic hydrolysis and synergistic cooperation between enzymes-Factors affecting enzymes, conversion and synergy. Biotechnol Adv 2012, 30:1458-1480

4. Hu J, Arantes V, Saddler JN: The enhancement of enzymatic hydrolysis of lignocellulosic substrates by the addition of accessory enzymes such as xylanase: is it an additive or synergistic effect? Biotechnol Biofuels 2011, 4:1-14.

5. Hu J, Arantes V, Pribowo A, Saddler JN: The synergistic action of accessory enzymes enhances the hydrolytic potential of a "cellulase mixture" but is highly substrate specific. Biotechnol Biofuels 2013, 6:112.

6. Schilling JS, Tewalt JP, Duncan SM: Synergy between pretreatment lignocellulose modifications and saccharification efficiency in two brown rot fungal systems. Appl Microbiol Biotechnol 2009, 84:465-475.

7. Chiranjeevi T, Rani G, Chandel AK, Sekhar PVS, Prakasham RS, Addepally U: Optimization of holocellulolytic enzymes production by Cladosporium cladosporioides using taguchi-L'16 orthogonal array. J Biobased Mater Bioenergy 2012, 6:148-157.

8. Chiaramonti D, Prussi M, Ferrero S, Oriani L, Ottonello P, Torre P, Cherchi F: Review of pretreatment processes for lignocellulosic ethanol production, and development of an innovative method. Biomass Bioenergy 2012, 46:25-35.

9. Berlin A, Balakshin M, Gilkes N, Kadla J, Maximenko V, Kubo S, Saddler J: Inhibition of cellulase, xylanase and $\beta$-glucosidase activities by softwood lignin preparations. J Biotechnol 2006, 125:198-209.

10. Grabber JH, Mertens DR, Kim H, Funk C, Lu F, Ralph J: Cell wall fermentation kinetics are impacted more by lignin content and ferulate cross-linking than by lignin composition. J Sci Food Agr 2008, 89:122-129.

11. Al-Zuhair S, Ahmed K, Abdulrazak A, El-Naas MH: Synergistic effect of pretreatment and hydrolysis enzymes on the production of fermentable sugars from date palm lignocellulosic waste. J Ind Eng Chem 2013, 19:413-415.

12. Jong E, Field JA, de Bont JAM: Evidence for a new extracellular peroxidase Manganese-inhibited peroxidase from the white-rot fungus Bjerkandera sp. BOS 55. Febs Lett 1992, 299:107-110.

13. Palma C, Martinez AT, Lema JM, Martinez MJ: Different fungal manganese-oxidizing peroxidases: a comparison between Bjerkandera sp. and Phanerochaete chrysosporium. J Biotechnol 2000, 77:235-245.

14. Paszczyński A, Huynh VB, Crawford R: Comparison of ligninase-I and peroxidase-M2 from the white-rot fungus Phanerochaete chrysosporium. Arch Biochem Biophys 1986, 244:750-765.

15. Kuwahara M, Glenn JK, Morgan MA, Gold MH: Separation and characterization of two extracelluar $\mathrm{H}_{2} \mathrm{O}_{2}$-dependent oxidases from ligninolytic cultures of Phanerochaete chrysosporium. Febs Lett 1984, 169:247-250

16. Tuisel H, Sinclair R, Bumpus JA, Ashbaugh W, Brock BJ, Aust SD: Lignin peroxidase $\mathrm{H} 2$ from Phanerochaete chrysosporium: purification, characterization and stability to temperature and $\mathrm{pH}$. Arch Biochem Biophys 1990, 279:158-166.

17. AsIma MS, Aishy A, Samra ZQ, Gull I, Athar MA: Identification, purification and characterization of a novel extracellular laccase from Cladosporium cladosporioioes. Biotechnol Biotec EQ 2012, 26:3345-3350.

18. Halaburgi VM, Sharma S, Sinha M, Singh TP, Karegoudar TB: Purification and characterization of a thermostable laccase from the ascomycetes 
Cladosporium cladosporioides and its applications. Process Biochem 2011, 46:1146-1152

19. Vijaykumar MH, Veeranagouda Y, Neelakanteshwar K, Karegoudar TB: Decolorization of 1: 2 metal complex dye Acid blue 193 by a newly isolated fungus, Cladosporium cladosporioides. World J Microbiol Biotechnol 2006, 22:157-162.

20. Bonugli-Santos RC, Durrant LR, Da Silva M, Sette LD: Production of laccase, manganese peroxidase and lignin peroxidase by Brazilian marine-derived fungi. Enzym Microb Technol 2010, 46:32-37.

21. Duncan SM, Farrell RL, Thwaites JM, Held BW, Arenz BE, Jurgens JA, Blanchette RA: Endoglucanase-producing fungi isolated from Cape Evans historic expedition hut on Ross Island, Antarctica. Environ Microbiol 2006, 8:1212-1219.

22. Margesin R, Schinner F: Properties of cold-adapted microorganisms and their potential role in biotechnology. J Biotechnol 1994, 33:1-14.

23. Kasana RC, Gulati A: Cellulases from psychrophilic microorganisms: a review. J Basic Microb 2011, 51:572-579.

24. Hamid B, Rana RS, Chauhan D, Singh P, Mohiddin FA, Sahay S, Abidi I: Psychrophilic yeasts and their biotechnological applications-a review. Afr J Biotechnol 2014, 13:2188-2197.

25. Fan H, Yang JS, Gao TG, Yuan HL: Removal of a low-molecular basic dye (Azure Blue) from aqueous solutions by a native biomass of a newly isolated Cladosporium sp.: kinetics, equilibrium and biosorption simulation. J Taiwan Inst Chem Eng 2012, 43:386-392.

26. Han Y, Chen H: Improvement of corn stover bioconversion efficiency by using plant glycoside hydrolase. Bioresour Technol 2011, 102:4787-4792.

27. Sticklen MB: Plant genetic engineering for biofuel production: towards affordable cellulosic ethanol. Nat Rev Genet 2008, 9:433-443.

28. Dong XQ, Yang JS, Zhu N, Wang ET, Yuan HL: Sugarcane bagasse degradation and characterization of three white-rot fungi. Bioresour Technol 2013, 131:443-451.

29. Zhang J, Moilanen U, Tang M, Viikari L: The carbohydrate-binding module of xylanase from Nonomuraea flexuosa decreases its non-productive adsorption on lignin. Biotechnol Biofuels 2013, 6:1-8.

30. Gerday C, Aittaleb M, Bentahir M, Chessa JP, Claverie P, Collins T, D'Amico S, Dumont J, Garsoux G, Georlette D, Hoyoux A, Lonhienne T, Meuwis MA, Feller G: Cold-adapted enzymes: from fundamentals to biotechnology. Trends Biotechnol 2000, 18:103-107.

31. Shi $H$, Zhang $Y$, Li $X$, Huang $Y$, Wang $L$, Wang $Y$, Ding $H$, Wang F: A novel highly thermostable xylanase stimulated by $\mathrm{Ca}^{2+}$ from Thermotoga thermarum: cloning, expression and characterization. Biotechnol Biofuels 2013, 6:26.

32. Rosgaard L, Pedersen S, Cherry JR, Harris P, Meyer AS: Efficiency of new fungal cellulase systems in boosting enzymatic degradation of barley straw lignocellulose. Biotechnol Prog 2006, 22:493-498.

33. Brunecky R, Alahuhta M, Xu Q, Donohoe BS, Crowley MF, Kataeva IA, Yang SJ, Resch MG, Adams MWW, Lunin W, Himmel ME, Bomble YJ: Revealing nature's cellulase diversity: the digestion mechanism of Caldicellulosiruptor bescii CelA. Science 2013, 342:1513-1516.

34. Srebotnik E, Hammel KE: Degradation of nonphenolic lignin by the laccase/1-hydroxybenzotriazole system. J Biotechnol 2000, 81:179-188.

35. Dias AA, Freitas GS, Marques GSM, Sampaio A, Fraga IS, Rodrigues MAM, Evtuguin DV, Bezerra RMF: Enzymatic saccharification of biologically pre-treated wheat straw with white-rot fungi. Bioresour Technol 2010, 101:6045-6050.

36. Salvachúa D, Martínez AT, Tien M, López-Lucendo MF, García F, Ríos V, Martínez MJ, Prieto A: Differential proteomic analysis of the secretome of Irpex lacteus and other white-rot fungi during wheat straw pretreatment. Biotechnol Biofuels 2013, 6:115.

37. Chen CL, Qi W, Wang JY: Microbial cocktail for bioconversion of green waste to reducing sugars. J Biosci Bioeng 2013, 115:82-85.

38. Morales-Sánchez D, Tinoco-Valencia R, Kyndt J, Martinez A: Heterotrophic growth of Neochloris oleoabundans using glucose as a carbon source. Biotechnol Biofuels 2013, 6:1-13.

39. Isikhuemhen OS, Mikiashvilli NA: Lignocellulolytic enzyme activity, substrate utilization, and mushroom yield by Pleurotus ostreatus cultivated on substrate containing anaerobic digester solids. J Ind Microbiol Biotechnol 2009, 36:1353-1362.
40. Dinis MJ, Bezerra RMF, Nunes F, Dias AA, Guedes CV, Ferreira LMM, Cone JW, Marques GSM, Barros ARN, Rodrigues MAM: Modification of wheat straw lignin by solid state fermentation with white-rot fungi. Bioresour Technol 2009, 100:4829-4835.

41. Pribowo AY, Hu J, Arantes V, Saddler JN: The development and use of an ELISA-based method to follow the distribution of cellulase monocomponents during the hydrolysis of pretreated corn stover. Biotechnol Biofuels 2013, 6:1-15.

42. Mamo G, Hatti-Kaul R, Mattiasson B: A thermostable alkaline active endo- $\beta$-1-4-xylanase from Bacillus halodurans S7: purification and characterization. Enzym Microb Technol 2006, 39:1492-1498.

43. Lin LL, Thomson JA: An analysis of the extracellular xylanases and cellulases of Butyrivibrio fibrisolvens H17c. FEMS Microbiol Lett 1991, 84:197-204

44. Herpoël I, Moukha S, Lesage-Meessen L, Sigoillot J, Asther M: Selection of Pycnoporus cinnabarinus strains for laccase production. FEMS Microbiol Lett 2000, 183:301-306.

45. Archibald FS: A new assay for lignin-type peroxidases employing the dye azure B. Appl Environ Microbiol 1992, 58:3110-3116.

46. Bentivenga $G$, Bonini C, D'Auria M, Bona AD, Mauriello G: Singlet oxygen mediated degradation of Klason lignin. Chemosphere 1999, 39:2409-2417.

47. Ververis C, Georghiou K, Christodoulakis N, Santas P, Santas R: Fiber dimensions, lignin and cellulose content of various plant materials and their suitability for paper production. Ind Crop Prod 2004, 19:245-254.

48. Miller GL: Use of dinitrosalicylic acid reagent for determination of reducing sugar. Anal Chem 1959, 31:426-428.

49. Lowry OH, Rosebrough NJ, Farr AL, Randall RJ: Protein measurement with the Folin phenol reagent. J Biol Chem 1951, 193:265-275.

\section{doi:10.1186/s13068-014-0130-x}

Cite this article as: Ji et al:: Synergy of crude enzyme cocktail from cold-adapted Cladosporium cladosporioides Ch2-2 with commercial xylanase achieving high sugars yield at low cost. Biotechnology for Biofuels 2014 7:130.

\section{Submit your next manuscript to BioMed Central and take full advantage of:}

- Convenient online submission

- Thorough peer review

- No space constraints or color figure charges

- Immediate publication on acceptance

- Inclusion in PubMed, CAS, Scopus and Google Scholar

- Research which is freely available for redistribution 